\title{
ISOLATION AND SURVIVAL OF YERSINIA ENTEROCOLITICA IN ICE CREAM AT DIFFERENT PH VALUES, STORED AT $-18^{\circ} \mathrm{C}$
}

\author{
Norma B. Barbini de Pederiva; Ana M. Stefanini de Guzmán*
}

Microbiología General. Facultad de Química, Bioquímica y Farmacia Universidad Nacional de San Luis, San Luis, Argentina.

Submitted: January 07, 1999; Returned to authors for corrections: May 07, 1999; Approved: July 03, 2000

\begin{abstract}
The presence of Yersinia enterocolitica was investigated in 203 samples of industrial (123) and nonindustrial ice cream (80). Two $Y$. enterocolitica strains were isolated from non-industrial ice cream, which suggests the possibility of post-manufacturing contamination. One strain was typed as B:1A, O: 3,50,51; lis $\mathrm{Xz}$, while the other one was biotyped as: B:1A but not serologically typed. Survival of $Y$. enterocolitica was investigated by inoculating nine samples of industrially manufactured ice cream to contain $20 \mathrm{CFU} / \mathrm{ml}$ of $Y$. enterocolitica and stored at $-18^{\circ} \mathrm{C}$ for 480 days. The inoculated samples were classified into three different groups according to their $\mathrm{pH}$ (Group 1: $\mathrm{pH}$ 4-5; Group 2: $\mathrm{pH}$ 5-6 and Group 3: pH 6-7). Viability was determined by a combination of direct plating and enrichment. In Group 1, Y. enterocolitica was not detected after 150 days of storage, while in Groups 2 and 3, this microorganism was isolated until day 480 of storage. These findings suggest that the survival time of $Y$. enterocolitica in ice cream stored at $-18^{\circ} \mathrm{C}$ is significantly $(\mathrm{p} \leq 0,05)$ lower at $\mathrm{pH}$ values under 5 .
\end{abstract}

Key words: Yersinia, isolation, survival, ice cream, $\mathrm{pH}$

\section{INTRODUCTION}

Yersinia enterocolitica is a gram-negative psychrotrophic enterobacterium causing intestinal and extraintestinal manifestations in humans. The virulence of $Y$. enterocolitica strains is due to a 64 to $75 \mathrm{~Kb}$ plasmid designated as pYV and to inv, ail genes of the chromosome (4). This microorganism can be transmitted by contaminated water and food and has been isolated from meat, meat products, fish, vegetables, milk and ice cream $(6,7,15,17)$.

The ingredients normally employed in the preparation of ice cream are water, milk, cream, fresh and dried fruit, eggs, artificial sweeteners, dyes and aromatizing and stabilizing products. Since, except for some aromatizing products, all these ingredients can contain a microbial load capable of affecting the product quality, ice cream mixes are normally pasteurized at temperatures well above those used for fluid milk (13).

Important alterations can occur in semi-liquid (soft) ice cream when stored for prolonged periods or after long distance transportation to reach retail centers. Contamination and microbial growth can also be favored by inadequate storage temperatures, as well as by improper manufacturing and handling conditions. The addition of fruit or other ingredients after pasteurization can significantly increase the risk of contamination (16).

Outbreaks of diseases associated to the consumption of ice cream are not common in countries where official pasteurization controls are regularly performed. The most common outbreaks are those caused by Salmonella spp $(1,10$, $11,14,18,20)$ or Staphylococcus intoxication. The latter is usually a consequence of contamination at storage temperatures that permit growth of this microorganism. Furthermore, if milk is maintained for a few hours at temperatures enabling the growth of Staphylococcus aureus, large amounts of heat-stable enterotoxins can be produced (16).

The purpose of this work was to investigate the presence of $Y$. enterocolitica in industrial and non-industrial ice cream and to determine the viability of this bacterium during long

\footnotetext{
* Corresponding author. Mailing address: Catedra de Microbiología General, Area Microbiología, Facultad de Química, Bioquímica y Farmacia, Universidad Nacional de San Luis, Chacabuco y Pedernera, 5700 San Luis, Argentina, Fax: (+54)652 31301. E-mail: steguz@unsl.edu.ar
} 
term frozen storage, taking into account that the usually accepted preservation period is 18 months (540 days).

\section{MATERIALS AND METHODS}

A total of 203 samples, consisting of 123 samples coming from industrial ice cream and 80 from non-industrial ice cream, were examined. The samples were obtained from retail centers in the city of San Luis, Argentina, and immediately analyzed for $Y$. enterocolitica. Nine samples of industrial ice cream with $\mathrm{pH}$ between 4 and 7 were contaminated with $Y$. enterocolitica and stored at $-18^{\circ} \mathrm{C}$. Survival was determined periodically.

\section{Bacterial strain}

One strain of Y. enterocolitica, WA P+ 0:8, kindly provided by Dr Kapperud, Norway, was used.

\section{Isolation and identification}

Ten grams of each sample were enriched in $90 \mathrm{ml}$ of phosphate-buffered saline (PBS) $\left(0.067 \mathrm{M} \mathrm{KH}_{2} \mathrm{PO}_{4}-\mathrm{Na}_{2} \mathrm{HPO}_{4}\right.$ and $0.145 \mathrm{M} \mathrm{NaCl}), \mathrm{pH} 7.6$, with addition of $1 \%$ sorbitol and $0.15 \%$ bile salts $\left(\mathrm{PBS}_{\mathrm{sb}}\right)$. The samples were incubated at $4{ }^{\circ} \mathrm{C}$ for 21 days and processed as follows: (a) isolation on MacConkey agar with addition of irgasan DP 300, $0.004 \mathrm{~g} / \mathrm{l}$ $\left(\mathrm{MC}_{\mathrm{i}}\right)$ (9) and on Salmonella-Shigella agar (SS), incubating at $25^{\circ} \mathrm{C}$ for $48 \mathrm{~h}$; (b) $0.5 \% \mathrm{KOH}$ treatment $(4.5 \mathrm{ml}$ ) (19), followed by isolation on $\mathrm{MC}_{\mathrm{i}}$ and SS. Typical Yersinia colonies were subjected to Gram staining and conventional biochemical tests: triple sugar iron agar, oxidase, lysine and ornithine decarboxylase, urease, phenilalanine deaminase, methyl red, Voges-Proskauer, citrate, indole, malonate, acetate, esculin hydrolysis, nitrate reduction, arginine deaminase, gelatin hydrolysis, acid production from glucose, sucrose, sorbitol, mannitol, arabinose, maltose, raffinose, rhamnose, lactose, xilose, cellobiose, trehalose, glycerol, dulcitol, adonitol, inositol and salicin (2).

Classification of biovar (B), serovar (O) and phagovar (Lis) was performed in the National Reference Center of the Pasteur Institute, Paris, France.

\section{Survival}

Nine industrial ice cream samples were classified according to their $\mathrm{pH}$ into Group 1 (pH 4-5); Group 2 (pH 5-6) and Group 3 (pH 6-7). Single 200-ml samples were inoculated with $1 \mathrm{ml}$ of a $Y$. enterocolitica suspension containing $4.10^{3} \mathrm{CFU} / \mathrm{ml}$ and stored at $-18^{\circ} \mathrm{C}$.

Viability was determined by direct plating and previous enrichment. The samples were assayed at the time of inoculation $\left(\mathrm{T}_{0}\right)$ and after 7, 30, 90, 150, 190,230 and 480 days of storage. At each sampling time, $0.1 \mathrm{ml}$ of ice cream was taken for direct plating on SS and $\mathrm{MC}_{\mathrm{I}}$ and $10 \mathrm{ml}$ were enriched in $90 \mathrm{ml}$ of $\mathrm{PBS}_{\mathrm{sb}}$ at $4^{\circ} \mathrm{C}$ for 21 days. The samples were post enriched in $\mathrm{KOH}-\mathrm{NaCl}$ and counts were performed by duplicate surface plating on $\mathrm{MC}_{\mathrm{i}}$. The necessary dilutions for counts were prepared in $0.1 \%$ peptone water and plates were incubated at $22^{\circ} \mathrm{C}$ for $24-48 \mathrm{~h}$. Typical $Y$. enterocolitica colonies were counted and confirmed by biochemical tests. The $\mathrm{pH}$ values of the nine samples were determined at each sampling time.

\section{Statistical studies}

Variance analysis and comparison by Tukey's method were used for statistical analysis of the results.

\section{RESULTS}

\section{Y. enterocolitica isolation}

No Y. enterocolitica strain was isolated from the 123 industrial ice cream samples studied, while two $(2.5 \%)$ were isolated from the 80 non-industrial ice cream samples, after enrichment. One of the strains was classified as B:1A; $\mathrm{O}: 3,50,51$; lis $\mathrm{X}_{\mathrm{z}}(4)$. The second strain was typed as $Y$. enterocolitica $\mathrm{B}: 1 \mathrm{~A}$ but not serologically typed. No isolations were obtained by direct plating.

\section{Y. enterocolitica survival}

$Y$. enterocolitica was isolated only at $\mathrm{T}_{0}$ by direct plating $\left(\mathrm{T}_{0}=20 \mathrm{CFU} / \mathrm{ml}\right)$. As regards $Y$. enterocolitica survival in previously enriched samples, a significant decrease was observed after 150 days of storage at $-18^{\circ} \mathrm{C}$ in the ice cream samples of Group 1 ( $\mathrm{pH} 4-5$ ), while in Groups 2 and 3 ( $\mathrm{pH} 5$ 6 and 6-7, respectively), no significant difference in counts was detected throughout the experiment (Figure 1).

\section{DISCUSSION}

Consumption of ice cream contaminated with enterobacteria such as Salmonella has been the cause of several outbreaks (1, $8,11,20)$. In addition, isolations of $Y$. enterocolitica have been obtained from samples of ingredients used in the production of ice cream, such as cream, eggs and pasteurized milk (17). Outbreaks of yersinionis have also been associated with consumption of contaminated water and food. (6)

The results obtained for the isolation of this microorganism from non-industrial ice cream, though low $(2.5 \%)$, indicate that this food constitutes a possible transmission path for $Y$. enterocolitica, and might lead to gastroenteritis outbreaks among children consuming great amounts of ice cream, particularly during the hot season.

The $Y$. enterocolitica survival studies in ice cream with different $\mathrm{pH}$ values without enrichment showed positive results only at the time of contamination $\left(\mathrm{T}_{0}\right)$. This is probably because, although pathogenic microorganisms are resistant to freezing temperatures, in certain bacteriologic media, particularly 


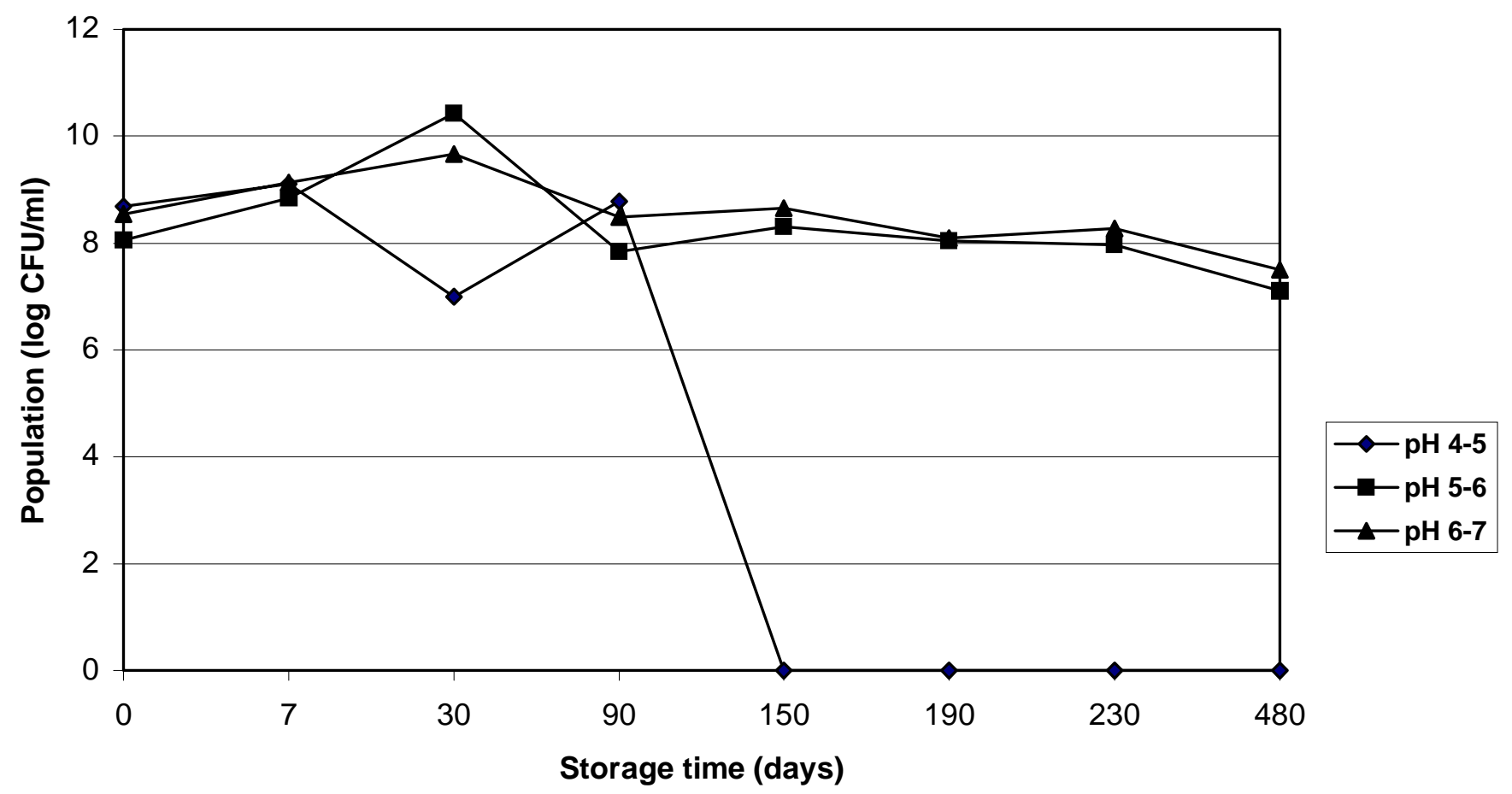

Figure 1. Survival of Yersinia enterocolitica in ice cream stored at $-18^{\circ} \mathrm{C}$.

selective ones, they can exhibit poor or no development. Therefore, enrichment procedures become necessary in order to detect pathogenic microorganisms in frozen food (12). At the storage temperature of ice cream $\left(-18^{\circ} \mathrm{C}\right)$, certain microorganisms can die slowly, inhibiting microbial multiplication (12).

Bhaduri et al. (3) reported no development of $Y$. enterocolitica at $\mathrm{pH} 4.5$ and low temperatures $\left(5\right.$ to $\left.19^{\circ} \mathrm{C}\right)$. Brackett (5) found that this bacterium remained viable at $\mathrm{pH} 4$ for at least 21 days at $5^{\circ} \mathrm{C}$. In the present study, $Y$. enterocolitica was recovered from samples with $\mathrm{pH} 4-5$ at $-18^{\circ} \mathrm{C}$ until at least 90 days after contamination.

Variance analysis for $\mathrm{p} \leq 0.05$ and Tukey comparison of the obtained results for recovery with enrichment did not show significant differences between the three groups until after 90 days. After 150 days, there was no difference between Groups 2 and 3, but there was no recovery in Group 1. In Groups 2 and 3, there was no significant difference in $Y$. enterocolitica recovery at the remaining sampling times, including that after 480 days, as compared to that at $\mathrm{T}_{0}$.

The results obtained may suggest that there is no possibility of $Y$. enterocolitica infection by consumption of ice cream with $\mathrm{pH}$ 4-5 (such as lemon flavor) after 150 days of contamination. However, the consumption of contaminated ice cream with $\mathrm{pH}$ 5-7 might lead to infection from the time of contamination until at least 480 days.

\section{ACKNOWLEDGEMENTS}

We thank Prof. Isabel Giménez for performing the statistical studies and Mr. Alfredo Villegas and Mr. Marcelo Villegas for their technical assistance. This work was supported by the Agencia Nacional de Promoción Científica y Tecnológica (Argentina), Project 5035 and by Universidad Nacional de San Luis, Project 8803.

\section{RESUMO}

\section{Isolamento e sobrevivência de Yersinia enterocolitica em sorvetes de distintos $\mathrm{pH}$, armazenados a $-18^{\circ} \mathrm{C}$}

Neste estudo pesquisou-se a presença de Yersinia enterocolitica em 203 amostras de sorvetes, sendo 123 de fabricação industrial e 80 de fabricação artesanal. Isolaram-se 2 cepas a partir de sorvetes artesanais, uma das quais foi caracterizada como B:1A, O:3,50, 51; lis Xz e a outra se tipificou como $Y$. enterocolitica $\mathrm{B}: 1 \mathrm{~A}$ mas não se tipificou sorologicamente, o que sugere uma contaminação pós processo. Em 9 dos sorvetes de fabricação industrial de distintos $\mathrm{pH}$, estudou-se a sobrevivência desse microrganismo, inoculandoos com $20 \mathrm{UFC} / \mathrm{ml}$ de $Y$. enterocolitica, quando armazenados durante 480 dias a $-18^{\circ} \mathrm{C}$. Esses sorvetes, segundo seu $\mathrm{pH}$, agruparam-se em: Grupo 1: pH: 4-5, Grupo 2: pH 5-6 e Grupo 
3: pH: 6-7. Determinou-se a viabilidade pelas curvas de morte usando semeadura direta e enriquecimento. Nos sorvetes do grupo $1, Y$. enterocolitica só foi detectada até o $150^{\circ}$ dia de armazenagem, enquanto que nas amostras dos grupos 2 e 3 , pelo menos até o $480^{\circ}$ dia da experiência. Nossos resultados mostram que a sobrevivência de $Y$. enterocolitica em sorvetes armazenados $\mathrm{a}-18^{\circ} \mathrm{C}$ foi significativamente menor $(\mathrm{p} \leq 0.05)$ em amostras com $\mathrm{pH}<5$.

Palavras-chave: Yersinia, isolamento, sobrevivência, sorvetes, $\mathrm{pH}$

\section{REFERENCES}

1. Armstrong, R. W., T. Fodor, G. T. Curtis, A. B. Cohen, G. K. Morris, W. T. Martin and F. Feldman. 1970. Epidemic Salmonella gastroenteritis due to contaminated imitation ice cream. Am J. Epidemiol. 91:300.

2. Bercovier, H.; Mollaret, H.H. Yersinia,. In Krieg, N. R. (ed), Bergey's manual of systematic bacteriology, vol 1. The Williams \& Wilkins Co., Baltimire, 1984, pp. 489-506.

3. Bhaduri S., R. L. Buchanan and J. G. Phillips. 1995.Expanded response surface model for predicting the effects of temperatures, $\mathrm{pH}$, sodium chloride contents and sodium nitrite concentrations on the growth rate of Yersinia enterocolitica. J. Appl. Bacteriol. 79:163-170.

4. Bottone E. J. 1997.Yersinia enterocolitica: The charisma continues. Clin. Microbiol. Rev. Vol. 10 (2): 257-276.

5. Bracket, R.E. Growth and suvival of Yersinia enterocolitica at acidic $\mathrm{pH}$ Int J Food Microbiol., 3, 243-251, 1986.

6. Chiesa C., L. Pacifico, V. Cianfranco, F. Nanni, A. Medici, S. Monto, P. Triglione, P. Mariani and M. Midulla. 1989. Sources of 2883 strains of Yersinia enterocolitica and related species isolated in Italy: Clinical ecological and epidemiological features. Microbiol. Ther. 18: 331-334.

7. Cover T. L., and Aber R.C. 1989. Medical Progress. Yersinia enterocolitica. N. Engl. J. Med. 321 ( 1 ): 16-21
8. Djuretic T., P. G. Wall, G. Nichols. 1997.General outbreaks of infectious intestinal disease associated with milk and dairy products in England and Wales: 1992 to 1996. Commun Dis Rep CDR Rev, 7(3): 41-45.

9. Escudero .E.M., L.Velázquez, A.M.S. Guzmán. 1995. Alternative enrichment techniques for Yersinia enterocolitica. Microbiol. Immunol. 13: 150-152.

10. Glosnicka R., D. Kunikowska. 1994. The epidemiological situation of Salmonella enteritidis in Poland. Int J Food Microbiol., 21(1-2): 21-30 .

11. Hennessy, T. W., C. W. Hedberg, L. Slutsker, K.E. White, J. M. Besser-Wiek, M. E. Moen, J. Feldman, W. W. Coleman, L. M. Edmonson, K. L. MacDonald and M. T. Osterholm. 1996. A national outbreak of Salmonella enteritidis infections from ice cream. The investigation team. N. Engl. J. Med. 334 (20): 1281-1286.

12. Instituto Internacional del Frío. Acribia (ed). 1990. In: Alimentos Congelados. Cap. 3: Principios generales de la congelación, almacenamiento y descongelación de los alimentos. p.27-30.

13. Lampert L. M. 1987. Ice cream and related products. In: Modern dairy products. Chemical Publishing Co., New York. p: 249-269.

14. Matsuo M., T. Takase, Y. Inoue, T. Ishino, Y. Tsuji and M. Kaku. 1995. Epidemic of Salmonella enteritidis infection of childhood in the northern area of Nagasaki. Kansenshogaku Zasshi. 69:291-296.

15. Schiemann D.A. 1987. Yersinia enterocolitica in milk and dairy products. $J$. Dairy Sci 70: 383-391.

16. Silliker J.H., R. P. Elliott, A. C. Baird-Parker, F.L.Bryan, J. H. B. B. Christian, D. S. Clark, J. C. Olson, T. A. Roberts. 1980. Acribia (ed). Leche y productos lácteos. In: Ecología microbiana de los alimentos. Vol. II, p. 498 - 502.

17. Tacket C. O., J. P. Narain, R. Sattin, J. P. Lofgren, C. Konigsberg, Jr., R. C. Rendtorff, A. Rausa, B. R. Davis, and M. L. Cohen. 1984. A multistate outbreak of infections caused by Yersinia enterocolitica transmitted by pasteurized milk. JAMA 251: 483 - 486.

18. Todd E. C. 1997. Epidemiology of foodborne diseases: a worldwide review. World Health Stat Q. 50(1-2): 30-50

19. Velázquez, L. del C.; Escudero, M. E.; Guzmán, A. M. S. de. Prevalence of Yersinia enterocolitica in hake (Merluccius hubbsi) fillets. J. Food Prot., 59, 7: 781-783, 1996.

20. Vought K. J., S. R. Tatini. 1998. Salmonella enteritidis contamination of ice cream associated with a 1994 multistate outbreak. J.Food Prot. 61 (1): 510 . 